\title{
The Impact of Financial Inclusion on Poverty in Jordan
}

\author{
Tamara Firas Al Maaytah ${ }^{1, ~ *, ~ T a l i b ~ M o h a m m a d ~ A w a d ~}{ }^{2}$ \\ ${ }^{1}$ Department of Business Economics, School of Graduate Studies, University of Jordan, Amman, Jordan \\ ${ }^{2}$ Department of Business Economics, School of Business, University of Jordan, Amman, Jordan
}

Email address:

firastamara@yahoo.com (T. F. Al Maaytah),talibawad@yahoo.com (T. M. Awad)

${ }^{*}$ Corresponding author

\section{To cite this article:}

Tamara Firas Al Maaytah, Talib Mohammad Awad. The Impact of Financial Inclusion on Poverty in Jordan. International Journal of Business and Economics Research. Vol. 9, No. 5, 2020, pp. 316-323. doi: 10.11648/j.ijber.20200905.14

Received: August 3, 2020; Accepted: August 17, 2020; Published: August 27, 2020

\begin{abstract}
This study aimed to estimate the long-run impact of financial inclusion along with a set of control variables on the poverty in Jordan during the period spans from 1980 through 2018. The per capita income growth rate was used as an indicator of poverty due to the lack of annual data on poverty indices. The study used the Autoregressive Distributed Lag (ARDL) Model to test for cointegration. Also, both Fully Modified OLS (FMOLS) and Dynamic OLS (DOLS) are used to estimate the long-run model parameters. The ADF (Augmented Dickey-Fuller) results indicate that the variables integrated of order one I(1) or integrated of order zero $\mathrm{I}(0)$ but none is $\mathrm{I}(2)$. The diagnostic statistical tests necessary to ensure the model's adequacy and validity indicate that the model is free from statistical problems, and the estimation results are reliable. The bounds test to cointegration provide evidence on the existence of long-run equilibrium relationship among variables, and hence, the variables are cointegrated. The empirical results revealed a positive effect of loans and demand deposits on per capita income, which reflects a reduction in poverty. While the number of bank branches has a negative impact on the per capita income, and hence, increasing poverty. Accordingly, the study recommended improving financial and banking systems to facilitate obtaining loans, increase the number of branches to improve individuals' access to financial services, and raising the interest rate on deposits to encourage investors and capital owners and companies to save in banks.
\end{abstract}

Keywords: Jordan, Poverty, Financial Inclusion, ARDL, Per Capita Income

\section{Introduction}

At the end of the twentieth century, financial and banking services assisted tremendous expansion and development; this is a result of technical progress, especially in the field of the Internet (the World Wide Web) for banking services, which helped to speed up its spread. These technologies have contributed to the innovation of financial instruments that helped all excluded groups of society in general, the poor people, women and youth in particular in accessing these financial instruments, which provide them with a sustainable standard of living [1]. Various forms of banking services have been provided, which provide new services to the nonbanks poor, for example: NGOs, commercial and governmental banks, insurance companies, credit card companies, and providers of wired and wireless services [2].

Poverty is still a major challenge in developing countries despite the rapid economic expansion in the region. The
International Monetary Fund (IMF) has urged that poverty reduction should be one of the primery development goals of countries. As the financial inclusion is considered an important factor in making the growth inclusive, therefore, it is neccessary to understand the relationship between financial inclusion and poverty at the local level to help policy makers design and implement programs that expand access to financial services, thereby reducing the level of poverty [3].

Referring to the difficulty in accessing financial services as one of the main factors that explain the persistence of poverty, therefore the role of financial development has been a controversial topic about poverty reduction strategies. The economic theories indicate that access to financial services allows the poor to improve investment and education, in addition to being a means that may lead to reduce poverty by helping the poor to diversify their sources of income through self-employment. In addition, developing the financial sector reduces the credit restrictions faced by poor families which 
limits their ability to make productive investments. [4].

Financial development contributes to reducing the level of poverty through two ways. First, directly by improving opportunities for the poor to access formal financing and enabling them to achieve sustainable livelihoods. Second, financial development can indirectly reduce poverty and income inequality by promoting economic growth and steering growth gains to the poor. One of the ways through which financial development promotes economic growth is by mobilizing funds from inefficient use to efficient use [5].

The main objective of this study lies in analyzing the role of financial inclusion in reducing poverty in Jordan over the study period, where most studies have confirmed that there is an inverse relationship between financial inclusion and the level of poverty, but does this relationship apply to the Jordan economy? That is why the importance of this study arise, as it is considered the first study, according to the researcher's best knowledge, to study the relationship between financial inclusion and the level of poverty in Jordan.

In order to show the extent of the impact of financial inclusion on poverty reduction in Jordan, the study will measure the significance of this effect by testing the following hypotheses which states that there is no statistically significant relationship between financial inclusion and poverty reduction in Jordan.

This study employes annual time series data for the period from 1980 to 2018. The data were obtained from various sources, such as the database of Central Bank of Jordan, the World Bank, the world development indicators (WDI). Additionally, the study employed the Autoregressive Distribution Lag Approach (ARDL) methodology to estimate the model parameters.

\section{Theoretical Framework}

Several studies have shown the inverse relationship between financial development (including financial inclusion) and poverty reduction. Schumpeter (1934) and McKinnon (1973) demonstrated that financial development can help reducing income inequality and poverty directly by providing Credit and financial services to the poor, which would help to increase their income by investing in productive activities, as well as through returns earned from savings. The Keynesian theory of money demand developed by McKinnon (1973) assumed that financial intermediaries were beneficial to the poor, even if they don't offer credit, because they offer opportunities for profitable savings, and help building capital or funds by accumulating savings as well as enabling the poor to get loans from these accumulated savings to start small and micro-enterprises (SMEs), and hence, generates revenue or returns. It ultimately reduces poverty by generating more jobs and increasing income [6].

Economists have paid attention in the nineties on the relationship between financial development, inequality and poverty, and classified theoretical research into three schools of thought, namely:

First: The inverted U-hypothesis: It is a theoretical model that predicts the inverted U-shaped relationship between financial development, poverty and economic development (G-J hypothesis). It is based on two investment opportunities: the first provides a safe but low return, while the second provides a high but more risky return. At the end, most individuals have access to financial services, and therefore financial development may increase income inequality or poverty in the early stages of development while tending to reduce income inequality or reduce poverty in addition to increasing average income [5].

Second: The inequality-narrowing hypothesis. This theory claims that financial development works to narrow the income gap. It stipulates that when the financial market grows, the previously excluded poor from obtaining loans will obtain the necessary financing for their investments. The development of the financial system improves the efficiency of capital allocation and reduces funding constraints in the financial market. Some economists have studied the role of wealth distribution in the macroeconomy by investing in human capital, and found that the initial short-run and longrun impacts of wealth on total production and investment with an inefficient credit market, and with the development of the credit market, increasing number of poor people are able to obtain sufficient funds and thus reduce income inequality [7]. Third: The inequality-broadening hypothesis is based on building a life cycle model with internal growth where individuals face restrictions on borrowing and thus they must decide during their youth how much time they devote and spend at education. This theory shows that financial development enables individuals with different incomes to make decisions about the need to invest in human capital. According to this hypothesis, financial development increases income inequality, as those with wealth earmarked for learning become entrepreneurs, while the poor are satisfied with primary education, and join the low-skilled unpaid labor market. Consequently, according to this theory, the rich get more benefit than the poor, especially when the financial system is weak, because the rich have guarantees to provide them for reverse loans, so it is difficult for the poor to obtain financing. Thus, income inequality will increase, so the relationship between financial development and income inequality will be positive. [5].

The direct effects of financial development on poverty reduction from theoretical point:

Financial sector development contributes directly in reducing the level of poverty and can help increasing the income of the poor in developing countries in several ways:

First: Financial intermediaries can directly reduce the level of poverty by facilating the access to the credit market and financial services to the poor, however, developing countries face multiple market difficulties in the financial sector, such as Asymmetric information and the high fixed costs associated with the small size of credit borrowing. These obsticles create risks in the advanced financial markets and thus prevent the poor from borrowing from formal financial institutions to invest in profitable activities. Some scholars have pointed out that a well-developed financial system can 
enhance the productivity of the poor by enabling them to access financial services, especially official credit, and thus enhance the productive assets of the poor and increase their potential to earn sustainable livelihoods [8].

Second: The disruption of the financial system leads to more income inequality in society by disproportionately distributing capital, and by keeping investors who suffer from a lack of wealth without financing from the financial sector. The disadvantages of the financial system impose credit restrictions that mainly affect the poor, as they have no guarantees of access to bank credit, and they do not have the resources to finance their own projects, and thus financial sector development can improve the efficiency of capital allocation by reducing the information gap that allows the poor to obtain external financing, hence financial development can play a vital role in reducing poverty [6].

Third: The evolving financial sector provides credit that facilities to the poor as well as savings opportunities, as Hicks (1937) theory demanding the money recast by McKinnon (1973) which assumed that financial intermediaries were beneficial to the poor, even if they did not provide credit, because they provided a profitable savings opportunity of business which helps to build capital by pooling savings and enabling the poor to borrow money from these accumulated savings to start small and micro enterprises besides earning benefits, which reduces the level of poverty by providing more job opportunities and increasing income.

Fourth: Many researchers believe that the development of the financial sector opens the door for many people to participate in the financial market, and therefore a large number of the population will enjoy the benefits of the financial sector, and thus the poor enjoy the benefits of financial development [9].

Indirect effects of financial development on poverty through economic growth:

In addition to the direct impact of financial development on reducing the level of poverty, financial development can indirectly affect the level of poverty by promoting economic growth, which contributes at /to poverty reduction [10].

Financial development enhances economic activity by increasing the demand of the labor component. In the event that the demand for/of labor increases, especially low-skilled workers, so this is an indirect impact of financial development and works to reduce the level of poverty. Thus, even if the financial development does not increase the direct use of financial services by the poor, it works to distribute income by increasing the demand for labor services provided by the poor and thus reducing poverty. But if the demand for skilled workers increases, the indirect impact of financial development on inequality and poverty reduction through the labor market will tend to enhance inequality and increase poverty [11].

The role of financial development in economic growth is an important issue; in the economic theory of development, it is believed that finance did not have an important role in promoting growth and that issues related to economic growth are technological progress and growth in the supply of employment only, according to Solow, 1956. But after the emergence of the subjective growth theory, this thought was changed. The theory of internal growth recognizes the positive effect of financial intermediaries on economic growth, and according to this theory, through a positive impact on capital mobilization and accumulation of savings, financial intermediation plays a reinforcing role in technology innovation and economic growth [12].

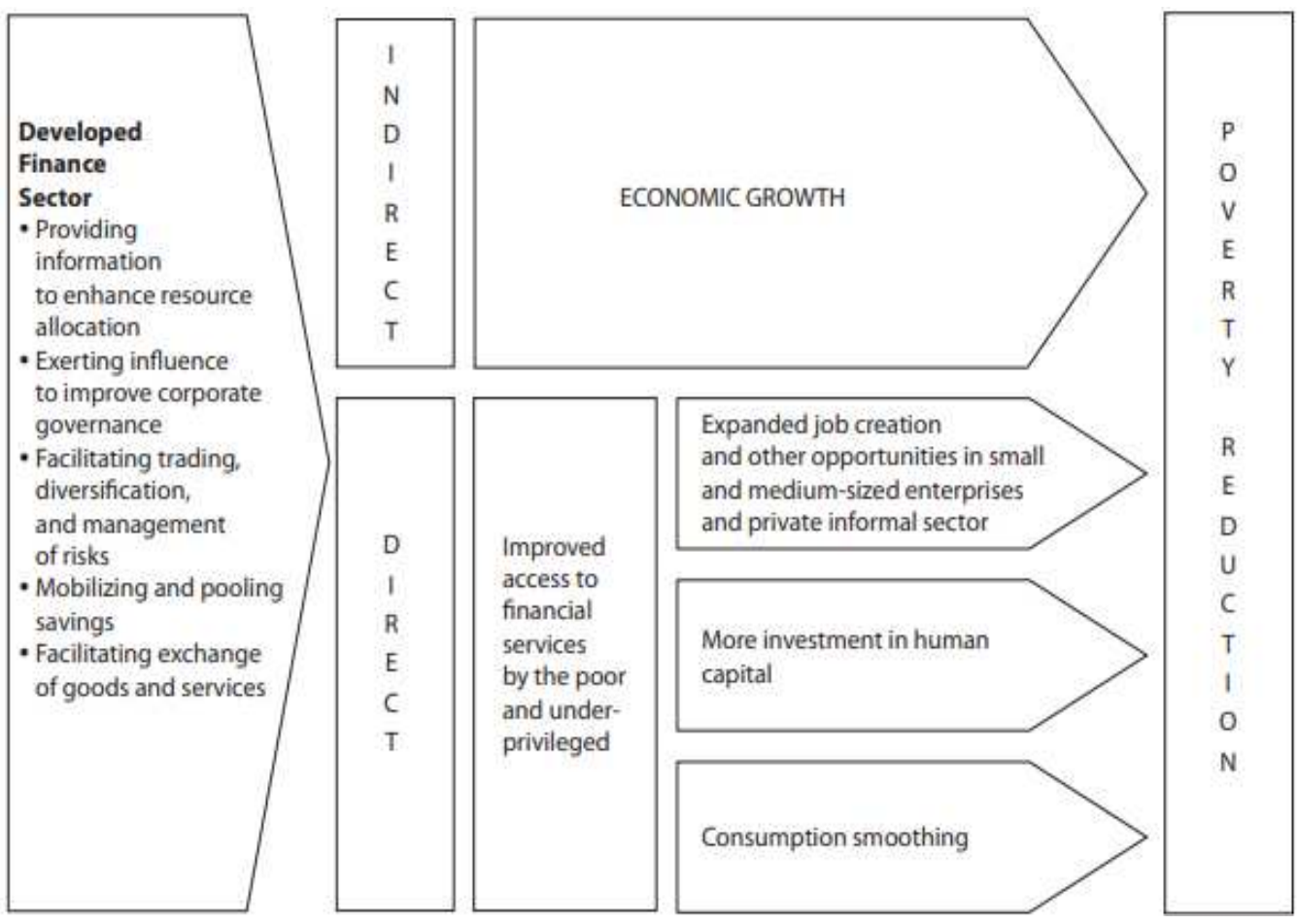

Figure 1. Channels of the impact of financial development on reducing the level of poverty. [13]. 


\section{Previous Studies}

Beck et al. by using the OLS methodology they found that financial development disproportionately boosts incomes of the poor and reduces income inequality. In addition to they found out that about $40 \%$ of the impact of financial development in the long run on income growth for the poor is a result of lower income inequality, while $60 \%$ is due to the impact of financial development on overall economic growth. They also found that financial development has an impact on a decrease in the proportion of the population living on less than $\$ 1$ a day. This led them to conclude the importance of the financial system to the poor. [9]

Zhang\& Chen also examined the relationship between financial development and income inequality in China during the period 1978-2013 by using automatic vector regression (SVAR). They reached concordant results with the G-J hypothesis of the inverted relationship between financial development and income inequality. As the results showed that the economy in its early stages of financial development will display increasing inequality, and only in the second or even third stages of development the inequality will decrease. [5]

Zahonogo studied how financial development affected poverty indicators in developing countries in 42 countries in sub-Saharan Africa for the period 1980-2012. And he used (GMM) Generalized Method-of-Moment. As the results showed that there is an end to financial development without which financial development will have harmful effects on the poor. In addition, financial development can be linked to less poverty. The results indicate an inverted U-type response, which therefore indicates the strength of the relationship between financial development and poverty in Sub-Saharan Africa. His findings show support for the view that claims the relationship between financial development and poverty reduction is not linear for sub-Saharan Africa. [4]

Jeanneney\& Kpodar explained in their study how financial development helps in reducing poverty directly through the influence of the McKinnon channel and indirectly through economic growth. Their findings, using data from a sample of developing countries during the period 1966-2000, indicate that the poor benefit from the ability of the banking system to facilitate transactions and provide savings opportunities, but they do not benefit from increased credit availability to some extent, and they concluded that financial development was accompanied by financial instability. It hurts/harms the poor. However, the benefits of financial development for the poor exceed the cost. [14]

Abdin assessed the impact of financial development and financial instability on reducing the level of poverty in Bangladesh between 1974-2013. The results indicate that financial development indirectly reduces poverty by promoting economic growth, directly by providing greater access to credit as well as the ability to save for the poor. Despite the positive effects of financial development on poverty reduction, the financial instability that arises alongside financial development impedes the process of poverty reduction [6].

Neaime \& Gaysset raised a question in their study: Is the burden of policymakers in the region creating effective opportunities for financial inclusion, and thus reducing poverty and income inequality? This was the question that they sought to address /process in this study. Using the GMM model Generalized Method of Moments in addition to Generalized Least Squares (GLS), the sample consisted of eight countries in the MENA region during the period 20022015, and they concluded that financial inclusion reduces income inequality, the size of Population and inflation increases income inequality. Also, financial inclusion has no impact on poverty, while it has been found that both population, inflation and trade openness increase poverty significantly. Finally, the results indicate that financial inclusion contributes positively at financial stability. [15]

Donou-Adonsou\& Sylwester researched how banks and smaller fund institutions reduce poverty in 71 developing countries during the period 2002-2011 using the simultaneous equations method, and they considered the credit variable of GDP as a key indicator of financial development. They concluded that banks reduce poverty when poverty is measured by the number of employees. However, smaller fund institutions have no impact on poverty, regardless of the poverty measure used. These findings indicate that while banks have some ability to reduce poverty, smaller fund institutions do not. [16]

Rewilak in his study shed light on the role of financial development in poverty reduction, where he divided development into four categories, and found that financial deepening has the greatest impact on poverty reduction followed by increased access to the financial system, and the results showed that the sector's inefficiency Banking has no effect on poverty reduction. While he also found during his study that financial instability may increase the incidence of poverty, and in his study also tried to shed light on new technological innovations in the financial sector, especially portable money, where he concluded that even when you control portable money, which may replace fixed branches, they may reduce the level of poverty. [17]

In contrast, the goal of Alomar is to demonstrate the impact of the evolution of the financial system on poverty reduction in developing countries, using cross-sectional data comprising 24 countries during the period 1985-1985 using the OLS method. And he concluded that there is a positive relationship of statistical significance between the effect of financial intermediation and poverty reduction, and that banking financial services increase the income of the poor. [18]

Park\& Mercado made it clear that poverty and income inequality is a challenge in Asia-Pacific countries despite of economic expansion in the region, which has lifted millions of its people out of poverty. They emphasized that understanding the relationship between financial inclusion, 
poverty and income inequality.

At the country level, will help policymakers to develop strategies that expand access to financial services, which reduces poverty and income equality, and this paper calculates the special financial inclusion index for 37 developing Asian economies. It also testifies the impact of financial inclusion on poverty and income inequality. The results showed that financial inclusion significantly reduces poverty and income inequality. They also pointed out that laws for residents and the elderly, such as pensions, will strengthen the rule of law, including financial contract enforcement and financial regulatory oversight, which expand financial inclusion, and thus contribute at poverty reduction and low income inequality. [3]

Jalilian\& Kirkpatrick studied the relationship between financial development and poverty reduction using 26 countries, including 18 developing countries. They use the financial assets of bank deposits and the net foreign assets as measures of the development of the financial sector. Their findings indicate that a 1 percent change in financial development increases income growth for the poor in developing countries by approximately 0.4 percent, which is a significant impact. [19]

\section{Econometric Model}

Reducing poverty in society is an important goal of financial inclusion. One of the methods of measuring poverty is the level of per capita income (PCI) where it is considered a dependent variable in this model, so that the high level of the PCI indicates a better standard of living while low level indicates an increase in the level of poverty. Financial inclusion is measured here by the number of bank branches
(BB), demand deposits (D) and loans (L) which are independent variables in addition to the variables that affect per capita income.

The study relies on measuring the impact of financial inclusion on poverty in Jordan on a model that some studies used a similar model like [20] and Kareem \& Aymond (2013) where they used the per capita income (PCI) to measure poverty.

We relied on the PCI as an indicator of poverty, because it is difficult to find an indicator for poverty (such as the poverty line $\mathrm{z}$ or the head census index $\mathrm{H}$ ) in which annual data are available for a long time series/periods, as the surveys available at the Jordanian Department of Statistics measure poverty rates in Jordan for intermittent periods, and the same applies to World Bank data For Jordan, where it was found that no data are available on poverty in Jordan, and therefore the only indicator about poverty is available to measure the impact of financial inclusion on poverty is PCI. Based on the theories and previous studies referred to abovementioned, the economotric model used in this paper takes the following form:

$$
P C I=f\left(L, D, B B, I N F, e_{t}\right)
$$

Whereas:

PCI: per capita income, which is a dependent variable, Lon is Loans, which is an independent variable, FD is the demand deposits which is an independent variable, $B B$ is The number of bank branches operating in Jordan, which is an independent variable, INF is the inflation rate, and $e_{t}$ is the random error term. All variables are in natural logarithm form except for the inflation rate. The logarithmic formula of the previous relationship is as follows:

$$
\log P C I=\beta+\alpha \log L o n+\delta \log F D+\theta \log B B+\gamma I N F+\mu_{t}
$$

whereas

$\beta$ : constant

$\alpha, \delta, \theta, \gamma:$ the parameters to be estimated

$\mu_{t}:$ random error

This study uses the data of the Central Bank of Jordan available on its database during the period (1980-1918)

In order to start the standard data analysis, a unit root test must be conducted in order to examine the properties of the time series, verify their range and determine the order of integration for each variable. If the series is stationary at the first difference, the original series is integrated of order I (1) and the series is considered stationary if the arithmetic mean is constant over time and the variance is constant over time [21]

There are several tests to determine the degree of integration of the time series. Augmented Dickey-Fuller test-ADF will be conducted. The hypotheses of the test are:

Augmented Dickey-Fuller test (ADF) The test is done by comparing the $\tau$ (tau) of the estimated parameter with the tabular statistical value $(\tau)$ if the absolute value of the statistic $(\tau)$ is greater than the absolute value of the Critical Value (C.V), it is statistically significant and therefore the time series is stationary, and if it is less than the C.V value, the alternative hypothesis will be accepted i.e. the series is nonstationary.

Table 1. ADF unit root test results.

\begin{tabular}{lllllll}
\hline & \multicolumn{3}{l}{ Level I (0) } & \multicolumn{3}{l}{ First deference I (1) } \\
\hline & \multicolumn{3}{l}{ Trend and intercept } & \multicolumn{3}{l}{ Trend and intercept } \\
\hline Variables & ADF & C. V & Prob & ADF & C. V & Prob \\
\hline LPCI & -2.55 & -4.23 & 0.30 & -3.52 & -3.54 & 0.0 \\
LBB & -5.29 & -4.21 & 0.00 & - & - & - \\
LFD & -2.87 & -4.23 & 0.18 & -3.77 & -3.53 & 0.02 \\
LLon & -3.29 & -3.20 & 0.08 & -3.72 & -3.53 & 0.03 \\
INF & -3.83 & -3.61 & 0.00 & - & - & - \\
\hline
\end{tabular}

The results of the ADF unit test show that the time series variables are stationary at the level, I $(0)$ or after taking the first difference I (1), where (BB), (INF) expresses the number of bank branches and the inflation rate, respectively. They were stationary at the level, while PCI, FD, and Lon are stationary at the first differenced. Since all variable are either I (0) or I (1) but not I (2), this allows us to use the Autoregressive Distributed Lag (ARDL) model.

One of (ARDL) developed by Pesaran and Shin (1998) 
advantages is that it shows short-run and long-run relationships between variables, and can be applied to integrated variables at the rank I (0) or I (1) or a combination between them, and the results are not biased and efficient, in addition to accepting small-sized samples [22].

The ARDL model takes the general form

$$
\Delta Y_{t}=\alpha_{0}+\sum_{j=0}^{q} \beta_{\mathrm{j}} \Delta X_{\mathrm{t}-1}+\sum_{i=1}^{p} \gamma_{i} \Delta Y_{\mathrm{t}-1}+\varphi_{1} \mathrm{X}_{\mathrm{t}-\mathrm{j}}+\varphi_{2} \mathrm{Y}_{\mathrm{t}-1}+\varepsilon_{\mathrm{t}}
$$

Where the symbol $\Delta$ denotes the change, $\varphi_{1}$ and $\varphi_{2}$ represents the long-run relationship between the variables.

$\beta, \gamma$ : represent the short-run relationship

In the ARDL model, the bound test was examined by using the Wald-Statistical Test for evaluating the variables in the unrestricted error correction model.

The bound test is performed in several steps. First: finding the long-run relationship between the variables according to

$$
\Delta \mathrm{Y}_{\mathrm{t}}=\alpha_{0}+\sum_{\mathrm{j}=0}^{\mathrm{q}} \beta_{\mathrm{j}} \Delta \mathrm{X}_{\mathrm{t}-\mathrm{j}}+\sum_{\mathrm{i}=1}^{\mathrm{p}} \gamma_{\mathrm{i}} \Delta \mathrm{Y}_{\mathrm{t}-\mathrm{i}}+\varphi \mathrm{ECM}_{\mathrm{t}-1}+\varepsilon_{\mathrm{t}}
$$

$E C M_{t-1}$ represent an error correction model that shows the speed of modification or correction. To verify for a long-run relationship, we make test F-Wald Test according to Pesaran et al, (2001). The two hypotheses are based on:

The null hypothesis assumes lack of long-run relationship $H_{0}: \varphi_{1}=\varphi_{2}=0$

The alternative hypothesis assumes a long-run relationship $H_{1}: \varphi_{1} \neq \varphi_{2} \neq 0$

The acceptance or rejection of the null hypothesis is based on a comparison of calculated $\mathrm{F}$ with its tabular values within the critical limits established by [23]

A table is made up of an upper bound which is the variables are integrated of I (1) degree, and the lower bound indicates that the variables are integrated of I $(0)$ degree. In the case that the calculated value of $(\mathrm{F})$ is greater than the upper bound, we reject the null hypothesis and we will accept the alternative i.e. there is a co integration or long-run equilibrium relationship. Whereas if the calculated $\mathrm{F}$ is less than the minimum, the null hypothesis which assumes that there is no shared integration or long-run relationship is accepted.

Table 2. F-Bounds Test

\begin{tabular}{lllll}
\hline Test Statistic & Value & Signif. & I (0) & I (1) \\
\hline \multirow{2}{*}{ F-statistic } & \multirow{2}{*}{71.52} & $10 \%$ & 2.2 & 3.09 \\
\multirow{2}{*}{$\mathrm{k}$} & & $5 \%$ & 2.56 & 3.49 \\
& \multirow{2}{*}{4} & $2.50 \%$ & 2.88 & 3.87 \\
& & $1 \%$ & 3.29 & 4.37 \\
\hline
\end{tabular}

Table 2 shows that the bound test for the model where the calculated value of $F$ is (71.52) if compared to the lower and upper bounds of the test is greater than the upper bound on the level of significance $1 \%$ whose value is (4.37) and therefore we accept the alternative hypothesis that confirms the existence of a long relationship heading from the independent variables to the dependent variable, which is PCI.
Table 3. Long-run elasticity by using an ARDL approach.

\begin{tabular}{lllll}
\hline Variable & Coefficient & Std. Error & t-Statistic & Prob. \\
\hline LLON & 0.331603 & 0.040833 & 8.120875 & 0 \\
LFD & 0.064229 & 0.025157 & 2.553126 & 0.0162 \\
LBB & -0.91487 & 0.083127 & -11.0057 & 0 \\
INF & -0.00201 & 0.000512 & -3.9262 & 0.0005 \\
C & 10.21669 & 0.309576 & 33.00218 & 0 \\
\hline
\end{tabular}

Table 4. Long-run parameters by using a Dlos approach.

\begin{tabular}{lllll}
\hline Variable & Coefficient & Std. Error & t-Statistic & Prob. \\
\hline LFDF & 0.050511 & 0.006212 & 8.131526 & 0 \\
LBBF & -0.10081 & 0.017584 & -5.73302 & 0 \\
LLON & 0.007267 & 0.003744 & 1.940986 & 0.0646 \\
INF & -0.00015 & $7.55 E-05$ & -1.92734 & 0.0664 \\
LPCIF (-1) & 0.825218 & 0.021448 & 38.47502 & 0 \\
LPCIF (-8) & -0.23804 & 0.005693 & -41.8147 & 0 \\
C & 3.451421 & 0.253318 & 13.62483 & 0 \\
\hline
\end{tabular}

Table 5. Estimated long-run coefficients using the FMOLS approach.

\begin{tabular}{lllll}
\hline Variable & Coefficient & Std. Error & t-Statistic & Prob. \\
\hline LLON & 0.005915 & 0.003331 & 1.775764 & 0.089 \\
LFDF & 0.045653 & 0.005325 & 8.572523 & 0 \\
LBBF & -0.08727 & 0.016262 & -5.3663 & 0 \\
INF & -0.00017 & $6.49 E-05$ & -2.53478 & 0.0185 \\
LPCIF (-1) & 0.842087 & 0.018116 & 46.48186 & 0 \\
LPCIF (-8) & -0.23444 & 0.004629 & -50.6433 & 0 \\
C & 3.253622 & 0.215456 & 15.10112 & 0 \\
\hline
\end{tabular}

The data were analyzed by several methods to confirm the results that appeared, Table 3, shows the estimation results of the ARDL model, while Table 4, shows the estimation results of Dols, and finally Table 5, shows the estimation results of FMOLS. All methods showed the same results in terms of signs, consequently the independent variable effect on the dependent variable, which is PCI, so the impacts of loans and deposits were positive for PCI, thus reduces poverty. The effects of both branches and inflation are negative on PCI, thus increasing poverty.

The main objective of studying the long-run parameters is 
to clarify the financial inclusion impact (callable loans, deposits and the number of branches) on the per capita income and thus any increase in the per capita income will lead to a reduction in the poverty rate. Where both callable loans and deposits express the use dimension of financial services, while the number of branches express the availability dimension of the financial services.

The table shows that all variables are significant. The positive effect of loans is shown on the level of per capita income, so the increase in loans by $1 \%$, will increase the per capita income PCI by $(0.331603 \%)$ and since increasing the per capita income expresses a decrease in the poverty rate, therefore any increase of the loans size to individuals leads to a reduction in the poverty rate and improve their livelihoods as they are considered as financing small projects sources.

The effect of callable deposits was positive, thus increasing the FD by $1 \%$ will increase the PCI by $(0.064229 \%)$ Subsequently the poverty rate will reduce by the same percentage.
The effect of bank branches numbers was negative, the increases of BB by $1 \%$ will reduce the PCI by $-0.91487 \%$, Subsequently the poverty rate will reduce by the same percentage. In the study made by [24] of the Financial Inclusion Determinants in Arab Nations, she indicates that the services variables dimensions represented by the number of branches while studying Jordan status are the less effective than other dimensions.

The effect of inflation appears negative, if the INF increases by $1 \%$, the PCI will decrease by $0.00201 \%$. As the per capita income rate expresses the level of poverty, its decrease means an increase in the level of poverty and this corresponds with the economic theory.

Through analyzing the financial inclusion dimensions on poverty, we notice that the usage dimension is effective in reducing the poverty rate through loans and deposits from the dimension of banking services availability by the number of branches.

So the long-run relationship is as follows:

$$
L P C I=10.2167+0.3316 * L L O N+0.0642 * L F D-0.9149 * L B B-0.00201 * I N F
$$

The error correction parameter is one of the most important points to consider in the ARDL model. Table 6 shows the error correction as it appeared with a negative and significant which means that the model corrects itself with a rate of (0.180492) annually in the long run after exposed a shock.

Table 6. The error correction parameter.

\begin{tabular}{lllll}
\hline Variable & Coefficient & Std. Error & t-Statistic & Prob. \\
\hline CointEq $(-1)^{*}$ & -0.180492 & 0.008047 & -22.4309 & 0 \\
\hline
\end{tabular}

When studying the stability of the model to identify if a structural change in its behavior appears over time during the period (1980-2018), a (CUSUM of Squares) test was used, where it was shown that the values of the error are located within the critical limits and at the level of significance of $5 \%$, which means that the capabilities are stable during the period (1980-2018).

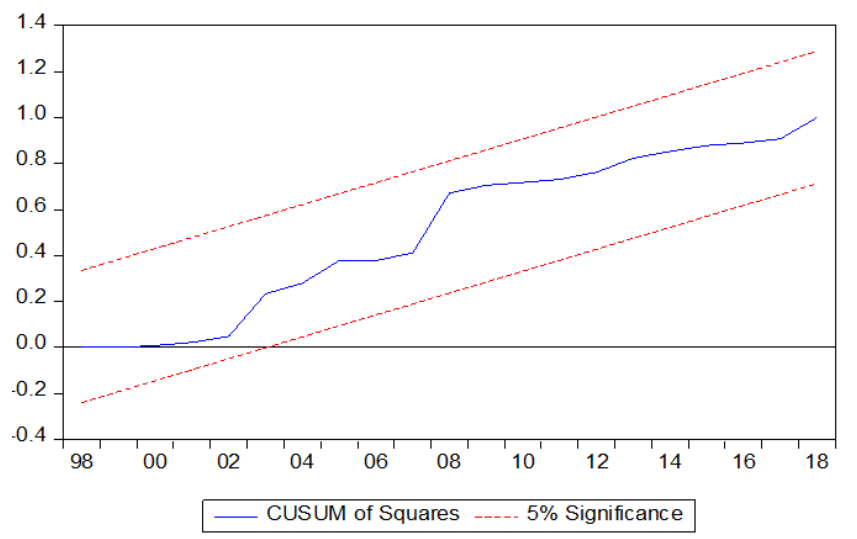

Figure 2. CUSUM of Squares.

\section{Conclusions}

After clarifying the theoretical framework for the study and achieving the desired goals of research and testing hypotheses, we reached to these results after analyzing Jordan's data:

1) The results of the unit root test showed that the variables are stable either on the level or after taking the first difference through the ADF test.

2) The analysis of the joint integration results between loans and the per capita income rate (as an indicator of poverty) showed that there is an integrative relationship in the short and long run, through testing bound, and therefore the loans affect positively on the per capita income, which reducing the poverty rate.

3) Consequently, the increase in granted loans by $1 \%$ leads to an increase in the rate of per capita income by $(0.331603 \%)$ which reduces poverty by the same percentage.

4) The results showed that the deposits impact on the income per capita is also positive. If it increases by $1 \%$, it will lead to an increase in the average per capita income by $(0.064229 \%)$ which the poverty rate will decrease.

5) The results showed that the impact of the bank branches number on the average person's income is negative, if it increases by $1 \%$, it will lead to a decrease in the average person's income by $0.91487 \%$.) which the poverty rate will rise.

6) The results showed that the inflation impact on the average person's income is negative. If it increases by $1 \%$, it will lead to a decrease in the average person's income by $0.00201 \%$ which increases the poverty rate.

\section{Recommendations}

Based on our findings, we suggest some recommendations.

1) The Central Bank of Jordan should facilitate the procedures for granting loans to individuals and small 
companies, as it has a positive impact in reducing the poverty rate which is one of the national financial inclusion strategy objectives.

2) Consider the number of active branches of banks in Jordan, and facilitate other ways that the individual can accomplish the financial requirements faster and save time and effort, such as expanding the spread of ATMs and automated deposits, and credit cards.

3) Create banking services that are more available and easier to use, such as activating services through the mobile, such as paying bills, shopping, and transferring between accounts, which is faster and Save money for individual that will dispense with the paper cash.

4) Raise the deposit benefit rate to encourage the capital owners and companies to increase savings.

5) Providing innovative banking services without need for bank branches to improve the opportunities of the poor to obtain financial services, provided they are appropriate in terms of quality, cost, transparency and fairness.

\section{References}

[1] Hamdan, Badr Shehadeh and Majed Mahmoud Abu Dayyeh (2018), The Impact of Financial Inclusion on Economic Development in Palestine, Economics and Finance magazine, file. 4, p. 2, Hassiba Ben Bou Ali University, Chlef, Algeria.

[2] Harrod Center (2018), Financial Inclusion in Egypt. Do lowincome people have a share in making financial instruments availability? Cairo Egypt.

[3] Park, C. Y., \& Mercado, R. (2015). Financial inclusion, poverty, and income inequality in developing Asia. Asian Development Bank Economics Working Paper Series, (426).

[4] Zahonogo, P. (2017). Financial development and poverty in developing countries: evidence from Sub-Saharan Africa. International Journal of Economics and Finance, 9 (1): 211220.

[5] Zhang, Q., \& Chen, R. (2015). Financial development and income inequality in China: An application of SVAR approach. Procedia Computer Science, 55, 774-781.

[6] Abdin, J. (2016). Financial development and poverty reduction: Exploring the links between the issues using evidence from Bangladesh. International Journal of Financial Research, 7 (4), 44-65.

[7] Ahmed, A. R., \& Masih, M. (2017). What is the link between financial development and income inequality? evidence from Malaysia.

[8] Levine, R. (2008). Finance and the Poor. The Manchester School, 76, 1-13.
[9] Beck, T., Demirgüç-Kunt, A., \& Levine, R. (2007). Finance, inequality and the poor. Journal of economic growth, 12 (1), 27-49.

[10] Caprio, G., \& Honohan, P. (2001). Finance for growth: policy choices in a volatile world. The World Bank.

[11] Beck, T., \& Demirguc-Kunt, A. (2009). Financial institutions and markets across countries and over time-data and analysis. The World Bank.

[12] Aghion, P., \& Howitt, P. (1990). A model of growth through creative destruction (No. w3223). National Bureau of Economic Research.

[13] Claessens, S., \& Feijen, E. (2007). Financial sector development and the millennium development goals. The World Bank.

[14] Jeanneney, S. G., \& Kpodar, K. (2011). Financial development and poverty reduction: can there be a benefit without a Cost? The Journal of development studies, 47 (1), 143-163.

[15] Neaime, S., \& Gaysset, I. (2018). Financial inclusion and stability in MENA: Evidence from poverty and inequality. Finance Research Letters, 24, 230-237.

[16] Donou-Adonsou, F., \& Sylwester, K. (2016). Financial development and poverty reduction in developing countries: New evidence from banks and microfinance institutions. Review of Development Finance, 6 (1): 82-90.

[17] Rewilak, J. (2017). The role of financial development in poverty reduction. Review of development finance, 7 (2), 169 176.

[18] Alomar, I. (2009). Ability of financial system to reduce poverty. Research Center, College of Business and economics, Qassim university, Saudi Arabia No. 75.

[19] Jalilian, H., \& Kirkpatrick, C. (2002). Financial development and poverty reduction in developing countries. International journal of finance \& economics, 7 (2), 97-108.

[20] Okoye, L. U., Erin, O., \& Modebe, N. J. (2017). Financial Inclusion as a Strategy for Enhanced Economic Growth and Development. The Journal of Internet Banking and Commerce, $1-14$.

[21] Gujarati, D. (2004). Basic Econometrics McGraw-Hill Book Co. New York, 387.

[22] Pesaran, M. H., \& Shin, Y. (1998). An autoregressive distributed-lag modelling approach to cointegration analysis. EconometricSociety Monographs, 31, 371-413.

[23] Pesaran, M. H., Shin, Y., \& Smith, R. J. (2001). Bounds testing approaches to the analysis of level relationships. Journal of applied econometrics, 16 (3), 289-326.

[24] Mohamed, R.(2019). Determinants of Financial Inclusion in the Arab World, Egypt Al-Moa'serah Journal Magazine, 110 (533), The Egyptian Association for Political Economy, Statistics and Legislation, Egypt. 